\title{
Effect of exogenous progesterone treatment on ovarian steroid hormones and oxidant and antioxidant biomarkers during peak and low breeding seasons in dromedary she-camel
}

\author{
Amal M. Abo El-Maaty ${ }^{1}$, Ragab H. Mohamed ${ }^{2}$, Heba F. Hozyen ${ }^{1}$, Adel M. El-Kattan ${ }^{3}$, Mona A. Mahmoud ${ }^{3}$ and Amal H. Ali ${ }^{1}$
}

1. Department of Animal Reproduction and Artificial Insemination, Veterinary Division, National Research Center, Dokki, Giza, Egypt; 2. Department of Theriogenology, Faculty of Veterinary Medicine, Aswan University, Egypt; 3. Department of Animal Health, Desert Research Center, Cairo, Egypt.

Corresponding author: Heba F. Hozyen, e-mail: drheba23@yahoo.com

Co-authors: AMAE: amalaboelmaaty@gmail.com, RHM: ragabhasan2016@gmail.com, AME: aelkattan@gmail.com, MAM: monaamahmoud@yahoo.com, AHA: amalali200180@yahoo.com

Received: 11-11-2018, Accepted: 26-02-2019, Published online: 17-04-2019

doi: 10.14202/vetworld.2019.542-550 How to cite this article: El-Maaty AMA, Mohamed RH, Hozyen HF, El-Kattan AM, Mahmoud MA, Ali AH (2019) Effect of exogenous progesterone treatment on ovarian steroid hormones and oxidant and antioxidant biomarkers during peak and low breeding seasons in dromedary she-camel, Veterinary World, 12(4): 542-550.

\section{Abstract}

Background: Research about the effects of progesterone $\left(\mathrm{P}_{4}\right)$ and the relationship of $\mathrm{P}_{4}$ to oxidative stress has been achieved in ruminants but not enough in camels. Aim: This study evaluated the effect of exogenous $\mathrm{P}_{4}$ hormone using CIDR for 7 days on blood concentrations of steroid
hormones and oxidative status of dromedary she-camels during peak and low breeding seasons.

Materials and Methods: The present work was conducted on ten dark dromedary she-camels which were synchronized using a controlled internal drug release (CIDR) for 7 days as a reproductive management tool during peak breeding (November-April) and low breeding season (May-October). The blood samples were collected each other day from CIDR insertion until the end of experiment 5 days after the removal of CIDR. Camels were examined for $\mathrm{P}_{4}$, estradiol ( $\left.\mathrm{E}_{2}\right)$, and testosterone (T) as well as malondialdehyde (MDA) as indicator of lipid peroxidation and nitric oxide, superoxide dismutase (SOD), and glutathione-S-transferase as antioxidant markers.

Results: Results revealed that $\mathrm{P}_{4}$ was higher during peak breeding season than low breeding season. While the levels of $\mathrm{P}_{4}$ increased during CIDR insertion and declined at CIDR removal and thereafter during breeding season, its concentrations declined after CIDR application during the non-breeding season. On the other hand, blood $\mathrm{E}_{2}$ and testosterone levels decreased after CIDR insertion in both high and low breeding seasons with higher serum $\mathrm{E}_{2}$ concentrations during the peak than the low breeding season. MDA concentrations and SOD activities were significantly $(\mathrm{p}<0.05)$ high on day 3 after CIDR insertion during the breeding and non-breeding seasons. During both the seasons, GSH levels decreased after CIDR removal in camels. However, MDA was lower during non-breeding season than high breeding season with no seasonal effect on SOD activity.

Conclusion: Exogenous $\mathrm{P}_{4}$ treatment through CIDR in dromedary camels could be more efficient during breeding season than non-breeding season, and effects on circulating oxidant/antioxidant biomarkers and their return to normal levels might refer to the adaptation of camels to CIDR by modulating their oxidant and antioxidant levels.

Keywords: breeding season, camel, controlled internal drug release, ovarian hormones, oxidant/antioxidant biomarkers.

\section{Introduction}

The one-humped camel (Camelus dromedarius) is an important animal in Africa and Asia having tremendous potential for milk, meat, and transport [1]. It is predicted that domestic camelids (camels, llamas, and alpacas) will be increasingly important for animal production in harsh environments due to their adaptive characteristics to desert [2]. However, dromedary camels are regarded as seasonal breeders with a relatively short breeding season during the cooler months [3]. Elevation of the ambient temperature

Copyright: El-Maaty, et al. Open Access. This article is distributed under the terms of the Creative Commons Attribution 4.0 International License (http://creativecommons.org/licenses/ by/4.0/), which permits unrestricted use, distribution, and reproduction in any medium, provided you give appropriate credit to the original author(s) and the source, provide a link to the Creative Commons license, and indicate if changes were made. The Creative Commons Public Domain Dedication waiver (http:// creativecommons.org/publicdomain/zero/1.0/) applies to the data made available in this article, unless otherwise stated. during summer seems to play the main role in affecting the camel reproductive activities through disturbance of the physiological activities [4]. In Egypt, the breeding season has been reported to be from December to May [5], during spring [6], and from December to August [7]. Synchronization of follicular waves is important for the development of fixed time artificial insemination and embryo transfer programs $[8,9]$. In camels, multiple approaches to synchronize follicular wave have been adapted from other species but met with variable results [2]. Moreover, there are conflicting reports on the efficacy of progesterone $\left(\mathrm{P}_{4}\right)$-releasing intravaginal devices (PRIDs) [10] and controlled internal drug releases (CIDRs) [7] in synchronization of follicular waves in camels. While camels treated for 17 days with PRIDs containing $1.9 \mathrm{~g} \mathrm{P}_{4}$ and receiving a large dose of equine chorionic gonadotropin (eCG) (3000 IU) had a better synchrony of follicular growth 
during breeding season [11], treatment with CIDRs containing $1.38 \mathrm{~g}$ of $\mathrm{P}_{4}$ for 10 days did not synchronize follicular waves in the non-breeding season [7]. On the contrary, estrus was induced in camels during the non-breeding season using eCG [12]. As well as, ovarian activity was also induced in Indian camels during the non-breeding season [13].

Reactive oxygen species (ROS) and antioxidant biomarkers have been detected in follicular fluid of dromedaries [14]. Oxidative stress occurs when the overproduction of the ROS could not be balanced by the production of antioxidants. This overproduction of ROS without sufficient antioxidant capacity results in oxidative damage that may cause many diseases including infertility [15]. Malondialdehyde (MDA) is one of the most frequently used indicators of lipid peroxidation [16] and it is a potential biomarker for oxidative stress as a biomarker of lipid peroxidation $[17,18]$. During various reproductive conditions, antioxidant such as superoxide dismutase (SOD) is naturally produced to prevent some disorders resulting from the overproduction of free radicals arising through oxidative phosphorylation and oxidase-catalyzed reactions $[15,19]$. In addition, glutathione-S-transferase (GST) plays a role in the biosynthesis of prostaglandins, $\mathrm{T}$, and $\mathrm{P}_{4}$ [20]. Nitric oxide (NO) is a short-lived inorganic free radical gas whose effects and the mechanism of action of NO depend strictly on its concentration, and consequently, NO may exert dual effects on the same process in the same cell $[21,22]$. NO is hardly measurable with direct methods because it is unstable gas having a very short half-life. However, it is rapidly converted into nitrites and nitrates which can be measured in biological fluids [23].

Considerable development and research were accomplished in the area of estrus synchronization and controlled breeding in ruminants. However, it is not the case in camels [24]. Studies on biochemical parameters are important for clinicians in the field, especially during programs utilizing progestin sources such as synchronization programs, artificial insemination, and embryo transfer [25]. This study evaluated the effect of exogenous $\mathrm{P}_{4}$ hormone using CIDR for 7 days on blood concentrations of steroid hormones and oxidative status of dromedary she-camels during peak and low breeding seasons.

\section{Materials and Methods}

\section{Ethical approval}

The animals during the experiment were handled in accordance with the use and animal care committee of Desert Research Center, Egypt.

\section{Animal and management conditions}

The experiment was conducted at MersaMatrouh Research Station, Desert Research Center, Egypt. A total of ten healthy one-humped, parous, non-pregnant camels of 9-13 years old (Camelus dromedarius) weighing $400-500 \mathrm{~kg}$ housed in semishaded pens under natural daylight and temperature were used. Animals were dewormed and vaccinated regularly. Camels were fed as one group on maintenance ration with concentrate mixture at the rate of $3-5 \mathrm{~kg} / \mathrm{head} /$ day in addition to Egyptian clover hay (Trifolium alexandrinum) and water was presented once daily.

\section{Experimental design}

During the breeding (March 2012) and non-breeding season (June 2012) [5], camels were treated with an EAZI-Breed CIDR insert containing $1.38 \mathrm{~g} \mathrm{P}_{4}$ (Hamilton, New Zealand) for 7 days [26]. The minimum and maximum temperatures in summer (June-August) were $22^{\circ} \mathrm{C}-35^{\circ} \mathrm{C}$ with $56.0 \%$ mean relative humidity (RH) and in spring (March-May) $15^{\circ} \mathrm{C}-28^{\circ} \mathrm{C}$ with $48.7 \% \mathrm{RH}$. No male camel was existed nearby females to avoid the induction of ovulation by introducing the male.

\section{Ultrasound examination}

SonoAce R2 Ultrasound Scanner (Medison, Samsung, South Korea), equipped with $12 \mathrm{MHz}$ linear array B-mode transducer, was used to examine the ovaries to assure the reproductive status of she-camel before application of CIDR.

\section{Blood sampling}

The blood samples were collected through jugular venipuncture each other day from the day following CIDR insertion (day 1) until day 5 after CIDR removal and then were allowed to clot, and after centrifugation at $3000 \mathrm{rpm}$ for $15 \mathrm{~min}$, sera were harvested and kept at $-20^{\circ} \mathrm{C}$ until measuring hormones, oxidants, and antioxidants.

\section{Measured parameters}

$P_{4}$

Quantitative $\mathrm{P}_{4}$ in serum was assayed using Enzyme immunoassay kits (Legal Manufacturer, DRG Instruments, GmbH, Germany) according to the method of Katt et al. [27]. The sensitivity was $0.05 \mathrm{ng} / \mathrm{ml}$, and intra- and inter-assay precisions were $5.9 \%$ and $10.1 \%$ for $\mathrm{P}_{4}$, respectively.

\section{Estradiol ( $\left.E_{2}\right)$}

Quantitative assay of serum $E_{2}$ [28] using Enzyme immunoassay kits (Legal Manufacturer, DRG Instruments, GmbH, Germany) was performed. The minimum detectable value was $2.0 \mathrm{pg} / \mathrm{mL}$ and the test precisions were $6.81 \%$ and $7.25 \%$ for $\mathrm{E}_{2}$.

\section{Testosterone}

Quantitative in vitro measurement of testosterone in serum according to Tietz [29] was performed using Enzyme immunoassay kits (Legal Manufacturer, DRG Instruments, GmbH, Germany). The sensitivity of the assay was $0.083 \mathrm{ng} / \mathrm{mL}$, and the inter- and intrarun precision coefficients of variation were 4.16 and 9.94\% for testosterone, respectively. 
$M D A$

MDA level was determined colorimetrically according to the method of Ohkawa et al. [30] using kits purchased from Biodiagnostic, Egypt.

NO

Endogenous nitrite concentration $\left(\mathrm{NO}^{2-}\right)$ as indicator of $\mathrm{NO}$ production in biological fluids was measured using Nitrite Assay Kit provided by Biodiagnostic, Egypt, according to Montgomery and Dymock [31].

SOD

SOD activity was estimated kinetically using SOD Assay Kits (Biodiagnostic, Egypt) according to Nishikimi et al. [32].

GST

GST activity was estimated kinetically using GST Assay Kits (Biodiagnostic, Egypt) according to Habig and Jakoby [33].

\section{Statistical analysis}

Data were presented as means \pm standard error of the mean. Statistical analyses of the data were performed using SPSS ${ }^{\circledR}$ software (SPSS Inc., Version 16, 2007, USA). Data were subjected to independent sample t-test to determine the effect of season (in and out). Simple one-way ANOVA was used to study the effect of the day within each season. Duncan's multiple range test was used to differentiate between significant means at $p<0.05$. Univariate General Linear Model ( 2 seasons * 7 days) was processed for every parameter, and tests between subjects' effects of treatment in and out season, days, and their interaction (days * treatment) were performed using Repeated Measures Analysis.

\section{Results}

Effect of exogenous $P_{4}$ treatment during breeding season and non-breeding seasons on $\left(P_{4}\right)$ concentrations $(\mathrm{ng} / \mathrm{ml})$ in serum of dromedary she-camel in Egypt

Figure-1 shows that $\mathrm{P}_{4}$ serum levels changed significantly $(\mathrm{p}<0.05)$ during different days of CIDR application in she-camels during breeding and non-breeding seasons. There was significant $(\mathrm{p}<0.02)$ interaction between CIDR treatment and time (Table 1). During the breeding season, a rapid increase in serum $\mathrm{P}_{4}$ concentration was observed on day 1 after CIDR insertion (1.55 \pm 0.18$). \mathrm{P}_{4}$ concentrations reached maximum values $(2.43 \pm 0.12) 5$ days after CIDR insertion, maintained high levels until day 7 , and then reached low values on day 5 after CIDR removal $(0.41 \pm 0.03)$. During the non-breeding season, $\mathrm{P}_{4}$ increased $24 \mathrm{~h}$ after CIDR insertion (1.61 \pm 0.12$)$, then descended gradually, and reached low values on day $3(0.54 \pm 0.04)$ and day $5(0.65 \pm 0.02)$ after CIDR removal. As shown in Table-1, the overall means of blood $\mathrm{P}_{4}$ concentration were significantly $(\mathrm{p}<0.05)$ lower during the non-breeding season in comparison with breeding season.

Effect of exogenous $P_{4}$ treatment during breeding season and non-breeding seasons on $E_{2}$ levels $(\mathrm{pg} / \mathrm{ml})$ in serum of dromedary she-camel in Egypt

During both the seasons, CIDR treatment as well as interaction of time and treatment had a significant $(p<0.05)$ effect on $E_{2}$ (Figure-2 and Table-1). During the breeding season, $\mathrm{E}_{2}$ concentrations declined from the day following CIDR insertion (65.42 \pm 8.88 ) and then reached significantly $(\mathrm{p}<0.05)$ low values (15.70 \pm 0.09$)$ on day 3 after CIDR removal and a significantly $(\mathrm{p}<0.05)$ high level on day $5(83.40 \pm 1.17)$. During the non-breeding season, $\mathrm{E}_{2}$ concentrations showed the highest value on the day of CIDR removal (69.43 \pm 8.08$)$, whereas the lowest value was noticed one day following CIDR insertion (27.19 \pm 3.59 ). It is clear from Table-1 that the overall means of blood $\mathrm{E}_{2}$ concentration were significantly $(\mathrm{p}<0.05)$ lower during CIDR in non-breeding season in comparison with breeding season.

Effect of exogenous $\mathrm{P}_{4}$ treatment during breeding season and non-breeding seasons on testosterone concentrations $(\mathrm{ng} / \mathrm{ml})$ in serum of dromedary shecamel in Egypt

As shown in Figure-3, testosterone gradually decreased during the breeding season till reach low values on the day of removing CIDR $(0.33 \pm 0.04)$, then increased till reach high value on day $3(1.46 \pm 0.13)$ after removing it. During the non-breeding season, testosterone concentrations showed a significant increase on days $3(1.81 \pm 0.06)$ and $5(1.90 \pm 0.09)$ following

Table-1: Effect of breeding season on $\mathrm{P}_{4}(\mathrm{ng} / \mathrm{ml}), \mathrm{E}_{2}(\mathrm{pg} / \mathrm{ml}), \mathrm{T}(\mathrm{ng} / \mathrm{ml}), \mathrm{MDA}(\mathrm{nmol} / \mathrm{ml}), \mathrm{NO}(\mu \mathrm{mol} / \mathrm{L}), \mathrm{SOD}(\mathrm{U} / \mathrm{ml})$, and GST in dromedary she-camels treated with CIDR for 7 days.

\begin{tabular}{|c|c|c|c|c|c|c|c|}
\hline \multirow[t]{2}{*}{ Breeding season } & \multicolumn{7}{|c|}{ Parameters } \\
\hline & $\begin{array}{c}\mathbf{P}_{4} \\
(\mathbf{n g} / \mathrm{ml})\end{array}$ & $\begin{array}{c}E_{2} \\
(\mathrm{pg} / \mathrm{ml})\end{array}$ & $\begin{array}{c}\text { Testosterone } \\
(\mathrm{ng} / \mathrm{ml})\end{array}$ & $\begin{array}{c}\text { MDA } \\
(\mathrm{nmol} / \mathrm{ml})\end{array}$ & $\begin{array}{c}\text { NO } \\
(\mu \mathrm{MOL} / \mathrm{L})\end{array}$ & $\begin{array}{l}\text { SOD } \\
(\mathrm{U} / \mathrm{ml})\end{array}$ & $\begin{array}{c}\text { GST } \\
(\mu \mathrm{MOL} / \mathrm{ml})\end{array}$ \\
\hline Peak breeding season & $1.97^{b} \pm 0.14$ & $53.66^{b} \pm 2.46$ & $1.05^{\mathrm{a}} \pm 0.06$ & $7.13^{b} \pm 0.19$ & $25.16^{\mathrm{a}} \pm 0.32$ & $310^{a} \pm 9.25$ & $4103^{a} \pm 190$ \\
\hline Low breeding season & $1.15^{\mathrm{a}} \pm 0.09$ & $45.86^{a} \pm 3.17$ & $1.55^{\mathrm{b}} \pm 0.04$ & $5.31^{\mathrm{a}} \pm 0.15$ & $26.43^{a} \pm 0.29$ & $321^{a} \pm 10.52$ & $5616^{b} \pm 490$ \\
\hline Season ( $p$-value) & 0.01 & 0.014 & 0.01 & 0.01 & 0.009 & 0.217 & 0.01 \\
\hline Season*Time ( $p$-value) & 0.02 & 0.015 & 0.01 & 0.03 & 0.042 & 0.038 & 0.029 \\
\hline
\end{tabular}

Data are presented as means \pm SEM. Means having different superscripts in the same column $(a, b)$ differ significantly between breeding and non-breeding seasons. GST=Glutathione-S-transferase, CIDR=Controlled internal drug release, $\mathrm{MDA}=$ Malondialdehyde, $\mathrm{SOD}=$ Superoxide dismutase, $\mathrm{NO}=$ Nitric oxide, $\mathrm{P}_{4}=$ Progesterone, $\mathrm{E}_{2}=$ Estradiol, $\mathrm{SEM}=\mathrm{Standard}$ error of the mean 
CIDR insertion compared to the low values one day following CIDR insertion (1.34 \pm 0.09$)$. Moreover, there were significant $(p<0.05)$ increases in overall means of blood testosterone during non-breeding season than breeding season (Table-1). It is clear from Table-1 that there was significant $(\mathrm{p}<0.01)$ interaction between exogenous $\mathrm{P}_{4}$ treatment and days of CIDR.

\section{Effect of exogenous $P_{4}$ treatment during breeding season and non-breeding seasons on MDA concen- trations $(\mathrm{nmol} / \mathrm{ml})$ in serum of dromedary she-camel in Egypt}

During the breeding season and non-breading seasons, days during treatment had a significant $(\mathrm{p}<0.05)$ effect on MDA (Figure-4). During the breeding season, MDA reached significant $(\mathrm{p}<0.05)$ value on day 3 after CIDR insertion (7.99 \pm 0.50$)$ and day $3(8.89 \pm 0.22)$ after CIDR removal. During the non-breeding season, MDA increased significantly $(\mathrm{p}<0.05)$ reaching high value on day 5 (6.97 \pm 0.77 ) following CIDR insertion, and after CIDR withdrawal, a reincrease was observed on day 5 (5.76 \pm 0.46$)$. Moreover, serum MDA was altered significantly $(\mathrm{p}<0.03)$ by interaction between days of CIDR and season (Table-1). It is also evident from values shown in Table- 1 that MDA $(\mathrm{p}<0.05)$ was significantly lower during non-breeding season than high breeding season.

Effect of exogenous $P_{4}$ treatment during breeding season and non-breeding seasons on NO concentrations $(\mu \mathrm{MOL} / \mathrm{L})$ in serum of dromedary she-camel in Egypt

Figure-5 clarifies that days during treatment in both the seasons had a significant $(\mathrm{p}<0.05)$ effect on NO which showed two peaks on day 7 on CIDR removal $(26.07 \pm 0.11)$ and day 3 after CIDR removal (27.46 \pm 0.78$)$. NO reached maximum values after CIDR insertion on day $1(27.61 \pm 0.85)$ and day 7 (29.40 \pm 0.51$)$. After CIDR withdrawal, however, NO decreased significantly $(\mathrm{p}<0.05)$ on day $3(23.51 \pm 1.03)$ then reached another peak on day 5 (26.12 \pm 1.28 ; Figure-5). However, no significant difference $(\mathrm{p}<0.05)$ was found in NO levels between high and low breeding seasons (Table-1).

Effect of exogenous $P_{4}$ treatment during breeding season and non-breeding seasons on SOD concentrations $(\mathrm{U} / \mathrm{ml})$ in serum of dromedary she-camel in Egypt

As shown in Figure-6, exogenous $\mathrm{P}_{4}$ treatment using CIDR in the breeding and non-breading seasons had a significant $(\mathrm{p}<0.05)$ effect on SOD. In addition, an interaction $(p<0.03)$ between treatment and days of CIDR was recorded as presented in Table-1. During the breeding season, SOD increased significantly and reached maximum values on day 3 followed by a significant decrease of SOD activity until the day of CIDR removal (334 \pm 29$)$ and rose again on day 1 after CIDR removal. During the non-breeding season, a significant increase of SOD activity was observed on day 7 when CIDR was removed $(434 \pm 230)$ and day 5 after its withdrawal $(422 \pm 35)$ compared to the

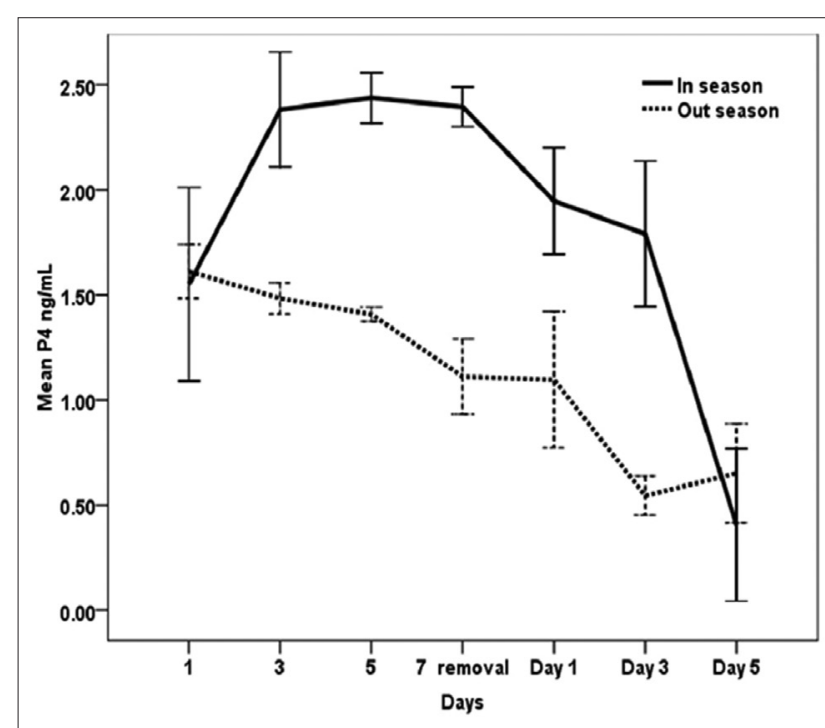

Figure-1: Effect of exogenous progesterone treatment during breeding season and non-breeding seasons on progesterone concentration $(\mathrm{ng} / \mathrm{ml})$ in serum of dromedary she-camel in Egypt.

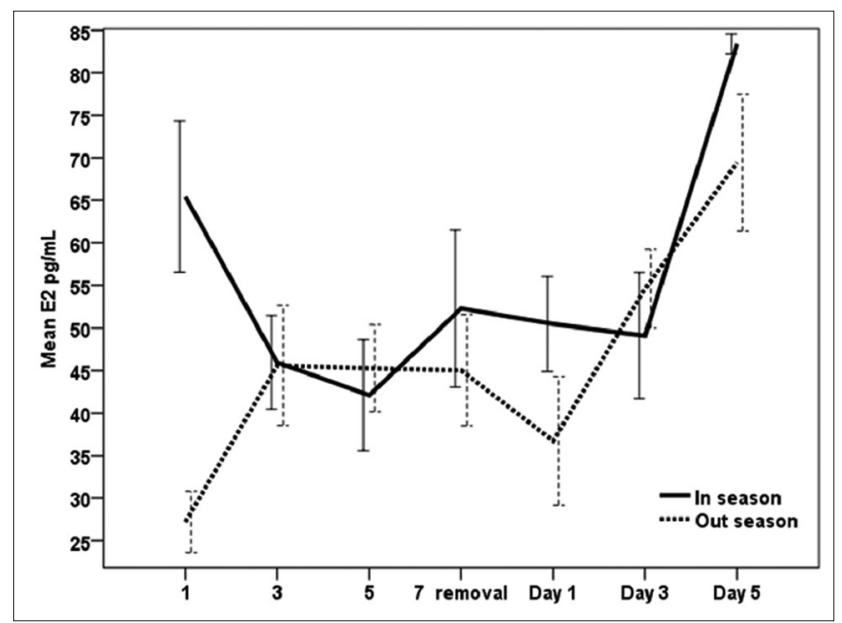

Figure-2: Effect of exogenous progesterone treatment during breeding season and non-breeding seasons on estradiol levels $(\mathrm{pg} / \mathrm{ml})$ in serum of dromedary she-camel in Egypt.

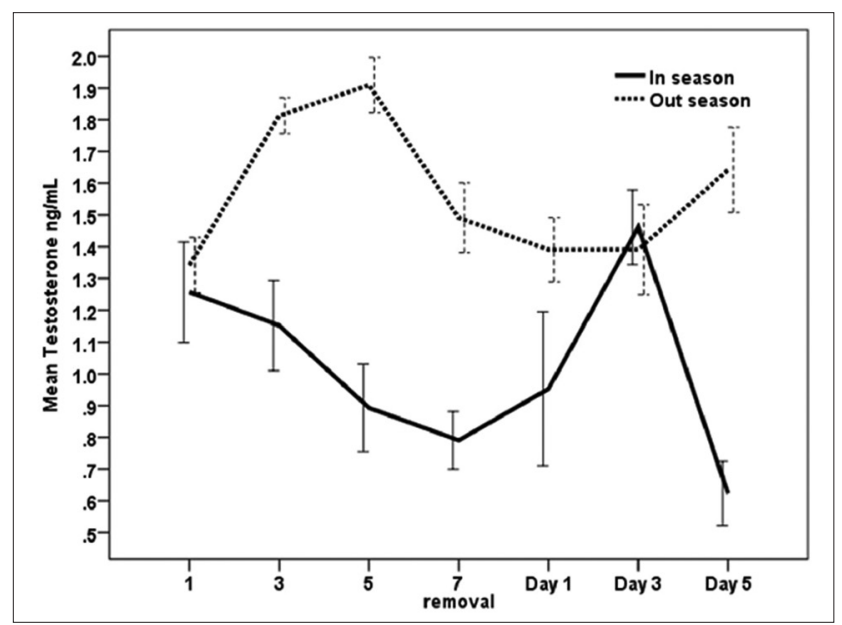

Figure-3: Effect of exogenous progesterone treatment during breeding season and non-breeding seasons on testosterone concentrations $(\mathrm{ng} / \mathrm{ml})$ in serum of dromedary she-camel in Egypt. 


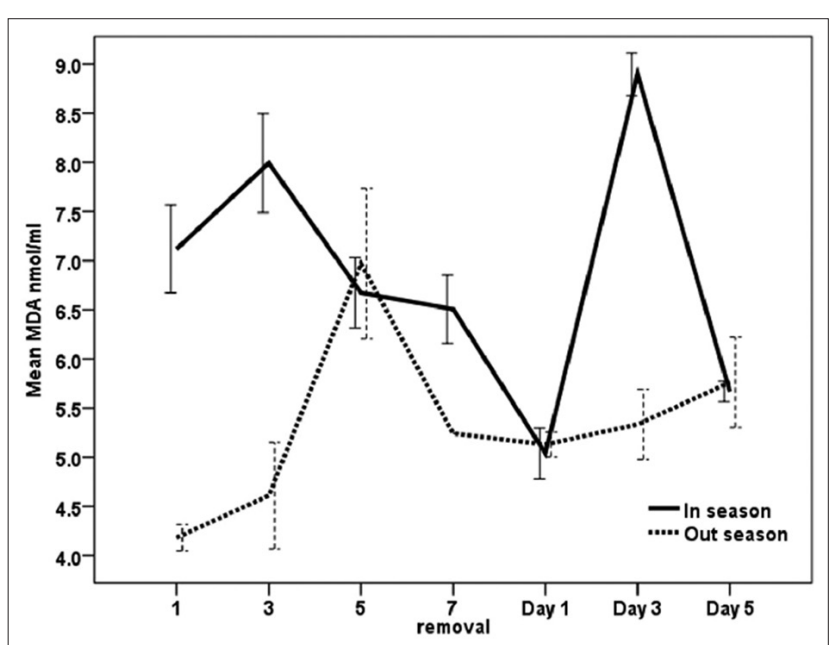

Figure-4: Effect of exogenous progesterone treatment during breeding season and non-breeding season on malondialdehyde concentration $(\mathrm{nmol} / \mathrm{ml})$ in serum of dromedary she-camel in Egypt.

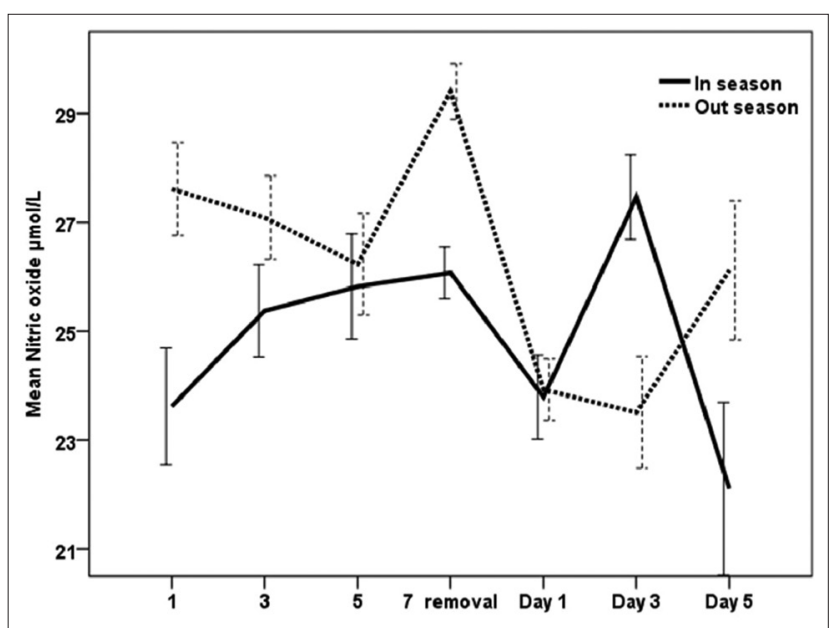

Figure-5: Effect of exogenous progesterone treatment during breeding season and non-breeding season on nitric oxide concentration $(\mu \mathrm{mol} / \mathrm{L})$ in serum of dromedary shecamel in Egypt.

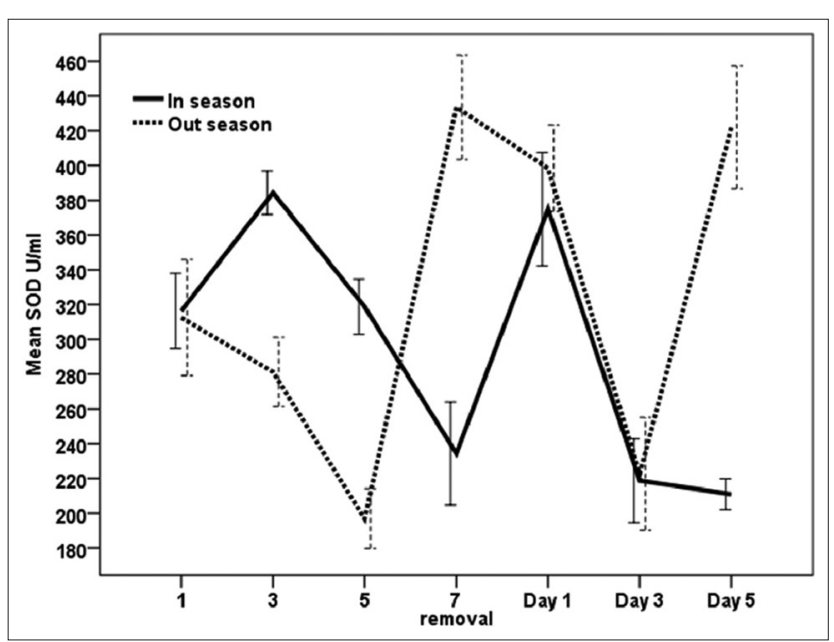

Figure-6: Effect of exogenous progesterone treatment during breeding season and non-breeding seasons on superoxide dismutase concentration $(\mathrm{U} / \mathrm{ml})$ in serum of dromedary she-camel in Egypt.

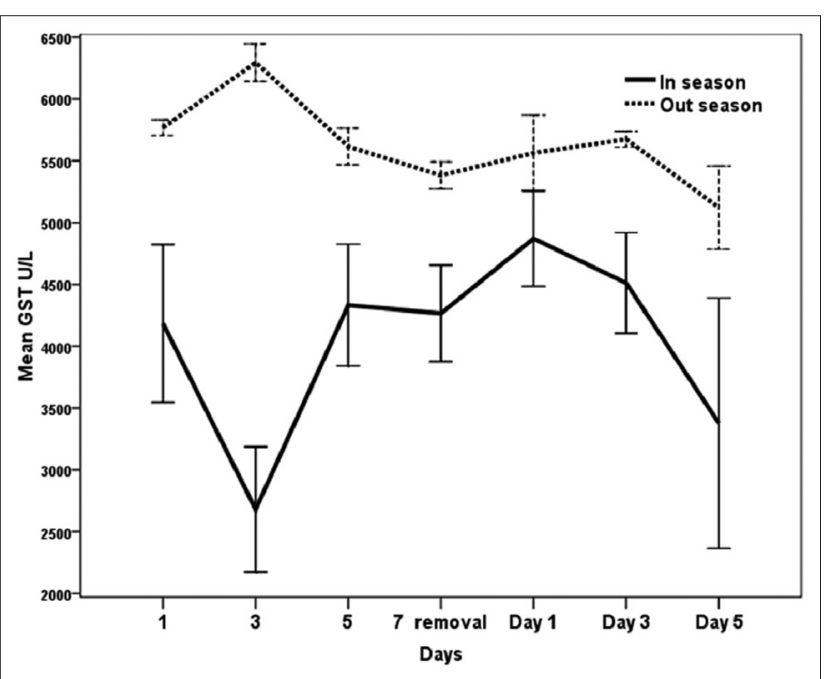

Figure-7: Effect of exogenous progesterone treatment during breeding season and non-breeding seasons on glutathione-S-transferase concentration $(\mu \mathrm{mol} / \mathrm{ml})$ in serum of dromedary she-camel in Egypt.

decrease of its activity on day $5(197 \pm 17)$ following CIDR insertion and day $3(223 \pm 32)$ after its withdrawal. However, no significant difference $(p<0.05)$ was found in SOD levels between high and low breeding seasons (Table-1).

Effect of exogenous $P_{4}$ treatment during breeding season and non-breeding seasons on GST concentrations $(\mu \mathrm{MOL} / \mathrm{ml})$ in serum of dromedary she-camel in Egypt

It is evident from Figure-7 that GST values during breeding season were significantly $(\mathrm{p}<0.05)$ lower on day $3(2680 \pm 506)$ before removing CIDR in comparison with its high values on days $1(4871 \pm 385)$ and $3(4511 \pm 407)$ after CIDR removal. In the non-breeding season, GST levels showed peak values on day 3 (6294 \pm 152$)$ during CIDR and descended to minimum values on day 7 of CIDR removal $(5382 \pm 109)$ and day 5 (5122 \pm 336 ) after CIDR removal (Figure-7). Meanwhile, GST was significantly $(\mathrm{p}<0.05)$ higher during the non-breeding season than breeding season (Table-1).

\section{Discussion}

In this study, $\mathrm{P}_{4}$ concentration was higher during peak breeding season when compared to non-breeding season. Moreover, synchronized she-camels exhibited a typical $\mathrm{P}_{4}$ profile during treatment days in the breeding season, as levels of $\mathrm{P}_{4}$ increased during CIDR insertion and declined at CIDR removal and thereafter. Conversely, $\mathrm{E}_{2}$ and testosterone concentrations decreased post-insertion of the CIDR and remained low until the day of removal, when they started to increase again. Similar to our dromedaries, llama treated with CIDR for 16 days showed a rapid increase in plasma $\mathrm{P}_{4}$ concentrations after the insertion of the intravaginal devices which reached peak values 1 day after insertion [34]. Moreover, there were interactions between treatment and days on serum levels of $\mathrm{P}_{4}$ and $\mathrm{E}_{2}$ as well as testosterone measured in 
the current work. These results are in partial agreement with those of Abd-El Hamid [35] who found a significant effect of interaction between treatment and days on levels of serum $\mathrm{P}_{4}$ in camels received CIDR (1.38 g) device for 10 consecutive days. On the other hand, the later author reported no interactions between days $(0,2,4,6,8,10,15,17$, and 20) and treatments on serum concentrations of $E_{2}$ in synchronized camels. According to Khalifa [36], the increase of $\mathrm{P}_{4}$ in peripheral circulation after CIDR insertion in she-camels is a result of effective absorption from vagina and removal of device would result in fast decline of the hormone in an expected way follow a biexponential curve. Skidmore et al. [25] reported that exogenous $\mathrm{P}_{4}$ could hasten the regression of large follicles, but it does not completely inhibit follicular growth in camels. However, in South American Camelids, Vaughan [37] found that 100 or $200 \mathrm{mg}$ of $\mathrm{P}_{4}$, administered IM every 2 days, was effective in inducing regression of the existing dominant follicle and preventing new wave emergence, whereas Chaves et al. [34], by evaluating follicular diameters and sexual hormones concentrations during treatment, stated that CIDR $(0.33 \mathrm{~g})$ could be effective in completely preventing follicular development for a period of up to 7 days. Swelum and Alowaimer [38] observed fall in $\mathrm{P}_{4}$ levels and emergence of a new follicular wave after 2-4 days after CIDR withdrawal during the breeding season of camels in Egypt. According to Monaco et al. [7], $\mathrm{P}_{4}$ administration through CIDR $(1.38 \mathrm{~g})$ for 10 days during beginning and in the middle of the non-breeding season of camels in Egypt was inefficient for synchronizing follicular waves. Nevertheless, the treatment did not affect mean follicular number, demonstrating its failure in controlling the emergence of new follicular waves. Female camels are seasonal breeders affected by long daylight during the warmest months of the year [39]. Based on the historical records over a period of 12 years (19992010), summer temperatures are extremely high in Egypt reaching $38^{\circ} \mathrm{C}-43^{\circ} \mathrm{C}$. Cairo subtropical climate is characterized by hot summer season extending from June to August with average minimum and maximum temperatures from $23^{\circ} \mathrm{C}$ to $35^{\circ} \mathrm{C}$ and $74 \%$ mean temperature humidity index [40]. The higher $\mathrm{P}_{4}$ levels during breeding season observed in the present study are in agreement with Babiker et al. [41] who reported an increase of $\mathrm{P}_{4}$ levels in female camels as an indicator of breeding season in dromedary camels in Sudan. On the other hand, Ali et al. [42] found higher serum $\mathrm{P}_{4}$ level during low than the peak breeding season in camels. The main source of serum $E_{2}$ is the Graafian follicles [42], and regression of the follicles, on the other hand, was followed by low estrogen and testosterone concentrations [43]. In this study, a dose of $1.38 \mathrm{~g} \mathrm{P}_{4}$ for 7 days for synchronization of estrus in she-camels induced significant decreases in $\mathrm{E}_{2}$ and testosterone blood levels during breeding season with higher serum $\mathrm{E}_{2}$ concentrations during the peak than the low breeding season. The changes in serum $\mathrm{E}_{2}$ levels in the present study could be attributed to the fact that ovarian growth of new follicles could be inhibited by progestin treatments [44]. The similar pattern of $\mathrm{E}_{2}$ and testosterone in dromedaries of this study and the association between the increase of $\mathrm{E}_{2}$ and testosterone concentrations after the removal of CIDR during both the seasons indicate their importance during follicle growth and maturation [45]. Plasma concentrations of testosterone were found to follow the same variations as peripheral concentrations of estrogen and increased size of the follicle is accompanied by an increase in peripheral concentrations of testosterone [46]. These results of $E_{2}$ in the current experiment are consistent with the findings of Hozyen et al. [47] who recorded a significant decline in $\mathrm{E}_{2}$ after insertion of CIDR in dromedary she-camels for 10 days. The decrease in $\mathrm{E}_{2}$ after CIDR insertion during the breeding season was also observed in llama treated with CIDR for 16 days, where $\mathrm{E}_{2}$ concentrations decreased drastically by day 1 post-insertion of the CIDR and remained low until day 6 , when $\mathrm{E}_{2}$ started to increase again [34]. Both $\mathrm{E}_{2}$ profiles and dominant follicle development attained a wave-like pattern in dromedaries and Lama guanicoe, showing a close relationship to follicle size $[46,48]$. On the other hand, Swelum and Alowaimer [38] revealed a non-significant difference in $\mathrm{E}_{2}$ levels during and after CIDR treatment in dromedary camels. In the non-breeding season, $E_{2}$ remained low or showed irregular, small increases due to incomplete waves of follicular development [46]. Similar to our results, higher plasma $\mathrm{E}_{2}$ concentrations were observed during peak breeding than low breeding season in camels [49]. Higher frequency of animals with active ovaries during the peak $(86.76 \%)$ than the low $(45.83 \%)$ breeding season were was in camel, and consequently, ovaries had more active follicles during the peak breeding season, resulting in higher serum $\mathrm{E}_{2}$ levels than the low breeding season [42].

Camels are well adapted to their environment by modulating their redox defense mechanisms against ROS and oxidative stress [50]. Ayres et al. [51] reported that lipid peroxidation is most often induced by $\mathrm{O}^{-2}$ and SOD catalyzes the reaction that converts $\mathrm{O}^{-2}$ to $\mathrm{H}_{2} \mathrm{O}_{2}$ and molecular oxygen. Furthermore, a number of studies have been conducted to measure NO levels to analyze oxidative stress. The obtained results in this work revealed that interactions between treatment and time significantly $(\mathrm{p}<0.05)$ affected measured oxidant and antioxidant biomarkers. There was a significant increase of MDA on day 3 after CIDR insertion and after CIDR removal during the breeding season and on the days 3 and 5 during CIDR in the non-breeding season. Moreover, NO levels increased on the day of CIDR removal during both the seasons and SOD activities were high on day 3 during CIDR and 1 day after CIDR removal during the breeding and the non-breeding seasons. On the other 
hand, GST decreased after CIDR insertion in both the seasons. This is in agreement with Oral et al. [52] who reported that PRID caused stress to the animals, and MDA and NO concentrations rose after device application procedures in healthy heifers and then returned to normal levels. In the same respect, the pattern of MDA during CIDR was also observed when CIDR was used in cows [53]. Increases in MDA levels could be attributed to vaginitis and stress that occurs after CIDR application and removal [53]. Moreover, the enzymatic antioxidant GSTs are capable of detoxifying several ROS produced during different physiological processes [20]. In the current work, different patterns of oxidant/antioxidant biomarkers were observed when comparing breeding and non-breeding seasons in camels treated with exogenous $\mathrm{P}_{4}$ for 7 days. As MDA in serum increased significantly during breeding season, SOD and GSTs were significantly higher during the non-breeding season when compared to breeding season. Increased oxidants such as MDA and NO in goats were related to increased serum $\mathrm{P}_{4}$ concentration after administration of intravaginal $\mathrm{P}_{4}$-releasing devices for estrus synchronization $[54,55]$. Furthermore, short-term PRID treatments increase serum $\mathrm{P}_{4}$ levels but decrease total antioxidant capacity in dairy heifers [23]. Elevated $\mathrm{P}_{4}$ and decreased $\mathrm{E}_{2}$ levels during breeding season in the present study were associated with increased NO and decreased SOD activities. The increase of NO on the day of CIDR removal during the breeding and the non-breeding seasons in the present work could confirm the association of low level of NO with the ovarian activity and follicle growth [15]. According to Gragasin et al. [56], estrogen improved the bioavailability of NO by modulating the function and expression of endothelial NO synthase.

\section{Conclusion}

From the present study, it could be concluded that: (1) The increase in $\mathrm{P}_{4}$ and decrease in $\mathrm{E}_{2}$ after CIDR insertion during the breeding season and the inverse pattern for these hormones during the non-breeding season could indicate that dose $1.38 \mathrm{~g}$ $\mathrm{P}_{4}$ for 7 days was efficient during the breeding season and not during the non-breeding season in Egyptian dromedary she-camels. (2) Alterations in concentrations of blood oxidant and antioxidant biomarkers after CIDR insertion and its return to normal levels refer to the adaptation of camels to CIDR by modulating their oxidants and antioxidants levels.

\section{Authors' Contributions}

RHM, AME, HFH, and MAM designed the experiment. HFH, AHA, and AMAE performed the analyses of all measured parameters. RHM, AME, and MAM provided the animals and carried out the experiment. AHA contributed to statistical analysis. HFH and AMAE drafted the manuscript. RHM, AME, MAM, and AHA helped to draft the manuscript. HFH and RHM reviewed the manuscript efficiently. All authors read and approved the final manuscript.

\section{Acknowledgments}

We acknowledge the financial support of this study from Desert Research Center and National Research Center, Egypt (grant no: P101204).

\section{Competing Interests}

The authors declare that they have no competing interests.

\section{Publisher's Note}

Veterinary World remains neutral with regard to jurisdictional claims in published institutional affiliation.

\section{References}

1. Mounir, K. and Borni, J. (2012) Reproductive Performance Improvement of Maghreby Nagga by Zootechic Practices. $3^{\text {rd }}$ ISOCARD International Conference, Muscat, Sultanate of Oman. p129-130.

2. Tibary, A. (2018) Monitoring and controlling follicular activity in camelids. Theriogenology, 109(3): 22-30.

3. Wilson, R.T. (1984) The Camel. Longman, London, New York. p83-102.

4. Marai, I.F., Zeidan, A.E., Abdel-Samee, A.M., Abizaid, A. and Fadiel, A. (2009) Camels' reproductive and physiological performance traits as affected by environmental conditions. Trop. Subtrop. Agroecosyst., 10(2): 129-149.

5. Shalash, M.R. (1965) Some reproductive aspects in the female camel. World Rev. Anim. Prod.,1(4): 103-108.

6. Abdel-Raouf, M. and El-Naggar, M.A. (1964) Studies on reproduction on camel Camelus dromedarius: 1 Mating technique and collection of semen. J. Vet. Sci. U. A. R., 1(2): 113-119.

7. Monaco, D., Lacalandra, G.M. and El-Bahrawy, K.A. (2013) Ovarian monitoring and effects of controlled intravaginal drug release (CIDR) on vaginal environment and follicular activity in dromedary camels, during non-breeding season in Egypt. Emir. J. Food Agric., 25(4): 296-300.

8. Anouassi, A. and Tibary, A. (2013) Development of a large commercial camel embryo transfer program: 20 years of scientific research. Anim. Reprod. Sci., 136(3): 211-221.

9. Vaughan, J., Mihm, M. and Wittek, T. (2013) Factors influencing embryo transfer success in alpacas a retrospective study. Anim. Reprod. Sci., 136(3): 194-204.

10. Cooper, M.J., Skidmore, J.A., Allen, W.R., Wensvoort, S., Billah, M., Chaudhry, M.A. and Billah,A. M.(1992)Attempts to Stimulate and Synchronise Ovulation and Superovulation in Dromedary Camels for Embryo Transfer. In: Proceedings $1^{\text {st }}$ International Camel Conference Dubai, UAE. p187-191.

11. Al-Sobayil K. (2008) The use of estrus synchronization and timed artificial insemination in dromedary she-camels in Saudi Arabia. J. Agric. Vet. Sci. Qassim Univ., 1(1): 3-9.

12. Ismail, A.A., Siam, A.A., El-Nahla, A. and Abuzead, S.M. (1998) Synchronization of Estrus in the She-Camel, Proceedings of the Third Annual Meeting for Animal Production Under Arid Conditions. Vol. 1. United Arab Emirates University. p96-107.

13. Agarwal, S.P., Rai, A.K. and Khanna, N.D. (1997) Induction of sexual activity in female camels during the non-breeding season. Theriogenology, 47(2): 591-600.

14. El-Shahat, K.H., Abo-El Maaty, A.M. and Moawad, A.R. (2013) Follicular fluid composition in relation to follicular size in pregnant and non-pregnant dromedary camels (Camelus dromedaries). Anim. Reprod., 10(1): 16-23.

15. Agarwal, A., Gupta, S. and Sharma, R.K. (2005) Role of 
oxidative stress in female reproduction. Reprod. Biol. Endocrinol., 3: 28.

16. Lykkesfeldt, J. (2007) Malonaldehyde as biomarker of oxidative damage to lipids caused by smoking. Clin. Chim. Acta, 380(1-2): 50-58.

17. Killic, E., Yazar, S., Saraymen, R. and Hozbilge, H. (2003) Serum malondialdehyde level in patients infected with Ascaris lumbricodes. World J. Gastroentrol., 9(10): 2332-2334.

18. Agarwal, A. and Allamaneni, S. R. (2004) Oxidants and antioxidants in human fertility. Middle East Fertil. Soc. J., 9(3): 187-197.

19. Chakraborty, P., Kumar, S., Dutta, D. and Gupta, V. (2009) Role of antioxidants in common health diseases. Res. J. Pharm. and Tech., 2(2): 238-244.

20. Nissar, S., Sameer, A.S., Rasool, R., Chowdri, N.A. and Rashid, F. (2017) Glutathione S transferases: Biochemistry, polymorphism and role in colorectal carcinogenesis. J. Carcinog. Mutagen., 8(2): 287.

21. Razzaque, W.A., Ali, R., Hussain, A., Rao, M.M., Naafia, S., Sharma, U. and Hussain, K. (2014) Follicular fluid nitric oxide concentration in relation to stages of estrus cycle in ewes. Indian Vet. J., 91(4): 35-38.

22. Zamberlam, G.O. (2013) The Involvement of Nitric Oxide in Bovine Follicular Development and Ovulation. Ph.D. Thesis, Université de Montréal.

23. Revelli, A., Piane, L.D., Casano, S., Molinari, E., Massobrio, M. and Rinaudo, P. (2009) Follicular fluid content and oocyte quality: From single biochemical markers to metabolomic. Reprod. Biol. Endocrinol., 7: 40.

24. Al Eknah, M.M. (2000) Reproduction in Old World camels. Anim. Reprod. Sci., 60-61:583-592.

25. Skidmore, J.A., Adams, G.P. and Billah, M. (2009) Synchronisation of ovarian follicular waves in the dromedary camel (Camelus dromedarius). Anim. Reprod. Sci., 114(1-3): 249-255.

26. Hussein, F.M., Metwelly, K.K., Mahmoud, M.A. and Mohamed, R.H. (2015) Effect of CIDR application duration (7-10-14 d) on circulating estrogen and progesterone during breeding and non-breeding season in she-camels. Alex. $J$. Vet. Sci., 44(1): 125-129.

27. Katt, J.A., Duncan, J.A., Herbon, L., Barkan, A. and Marshall J.C. (1985) The frequency of gonadotropin-releasing hormone stimulation determines the number of pituitary gonadotropin-releasing hormone receptors. Endocrinology, 116(5): 2113-2115.

28. Wramsby, H., Sundstorm, P. and Leidholm, P. (1987) Pregnancy rate in relation to number of cleaved eggs replaced after in vitro-fertilisation of stimulating cycles monitored by serum levels of oestradiol and progesterone as sole index. Hum. Reprod., 2(4): 325-328.

29. Tietz, N.W. (1986) Textbook of Clinical Chemistry. Saunders, Philadelphia, PA.

30. Ohkawa, H., Ohishi, W. and Yagi, K. (1979) Assay for lipid peroxides in animal tissues by thiobarbituric acid reaction. Anal. Biochem., 95(2): 351-358.

31. Montgomery, H.A.C. and Dymock, J.F. (1961) The determination of nitrite in water. Analyst, 86: 414-416.

32. Nishikimi, M., Rao, A. and Yagi, K. (1972) The occurrence of superoxide anion in the reaction of reduced phenazine methosulphate and molecular oxygen. Biochem. Biophys. Res. Commun., 46(2): 849-854.

33. Habig, W.H. and Pabst, M.J. (1974) Glutathione S-transferases. The first enzymatic step in mercapturic acid formation. J. Biol. Chem., 249(22): 7130-7139.

34. Chaves, M.G., Aba, M.A., Guero, A., Egey, J., Berestin, V. and Rutter, B. (2002) Ovarian follicular wave pattern and the effect of exogenous progesterone on follicular activity in non-mate d llamas. Anim. Reprod. Sci., 69(1-6): 37-46.

35. Abd-El Hamid, I.S.I. (2015) Using Different Regimens of Progesterone Hormone on Synchronization of Ovarian Activity in One-Humped She-Camels, Ph. D. Thesis.
Graduate School Faculty of Agriculture, Alexandria University, Egypt.

36. Khalifa, M.A. (2011) Manipulation of Postpartum Fertility in one-Humped She-Camels During the Non-Breeding Season Under Semi-Aria Condition, Thesis. Faculty of Agriculture, Alexandria University, Egypt.

37. Vaughan, J.L. (2011) Ovarian function in South American camelids (alpacas, llamas, vicunas, guanacos). Anim. Reprod. Sci., 124(3): 237-243.

38. Swelum, A.A. and Alowaimer, A.N. (2015) The efficacy of controlled internal drug release (CIDR) in synchronizing the follicular wave in dromedary camels (Camelus dromedarius) during the breeding season. Theriogenology, 84(9): 1542-1548.

39. Sumar, J.B. (1999) Reproduction in South American domestic camelids. J. Reprod. Fertil. Suppl., 54: 169-178.

40. Nour El-Din, M.M. (2013) Proposed Climate Change Adaptation Strategy for the Ministry of Water Resources and Irrigation in Egypt. Joint Programme for Climate Change Risk Management in Egypt.

41. Babiker, E.A., Ahmed, A.I., Husna, M.E. and AbdelAziz, B.E. (2011) Serum testosterone and progesterone levels and ovarian activity as indicators for seasonal breeding in dromedary camels in Sudan. Res. Opin. Anim. Vet. Sci., 1(5): 309-312.

42. Ali, S., Ahmad, N., Akhtar, N., Rahman, Z.U. and Noakes, D.E., (2008) Metabolite contents of blood serum and fluid from small and large-sized follicles in dromedary camels during the peak and the low breeding seasons. Anim. Reprod. Sci., 108(3-4): 446-456.

43. Khalil, M.G.R. (1989) Hormonal Control of Oestrous Cycle of the Camel (Camelus dromedarius). MVSc Thesis University of Khartoum, Sudan.

44. Ghoneim, I.M., Waheed, M.M., Adam, M.I. and Al-Eknah, M.M. (2015) Relationship between the size of the dominant follicle, vaginal electrical resistance, serum concentrations of oestradiol and progesterone and sexual receptivity during the follicular phase of the dromedary camel (Camelus dromedarius). Anim. Reprod. Sci., 154: 63-67.

45. Homeida, A.M., Khalil, M.G.R. and Taha, A.A.M. (1988) Plasma concentrations of progesterone, oestrogens, testosterone and LH-like activity during the oestrus cycle of the camel (Camelus dromedarius). J. Reprod. Fertil., 83(2): 593-598.

46. Skidmore, J.A. (2011) Reproductive physiology in female old world camelids. Anim. Reprod. Sci., 124(3-4): 148-154.

47. Hozyen, H.F., Mohamed, R.H. and Abo-El Maaty, A.M. (2017) Effect of using controlled internal drug release (CIDR) for enhancing reproductive performance on serum cortisol, ascorbic acid, progesterone and estradiol in dromedary she-camel. Bull. N. R. C., 41(2): 111-120.

48. Manjunatha, B.M., Pratap, N., Al-Bulushi, S. and Hago, B.E. (2012) Characterization of ovarian follicular dynamics in dromedary camels (Camelus dromedarius). Theriogenology, 78(5): 965-973.

49. Chamany, M. and Khazali, H. (1998) Determination of Estrogen and Progesterone in Breeding and Non-Breeding Season of the Pre and Pubertal Dromedarius Camels, Presented at $3^{\text {rd }}$ Annual Meeting for Animal Production under Arid Conditions (Camel Production and Perspectives), UAE, Al-Ain. p19.

50. Al-Otaiba, A., John, A., Al-Belooshi, T. and Raza, H. (2010) Redox homeostasis and respiratory metabolism in camels (Camelus dromedaries): Comparisons with domestic goats and laboratory rats and mice. J. Comp. Physiol. B, 180(8): 1121-1132.

51. Ayres, S., Abplanalp, W., Liu, J.H. and Subbiah, M.T.R. (1998) Mechanisms involved in the protective effect of estradiol-17b on lipid peroxidation and DNA damage. Am. J. Physiol. Endocrinol. Metab., 274(37): 1002-1008.

52. Oral, H., Öğün, M., Kuru, M. and Kaya, S. (2015) 
Evaluation of certain oxidative stress parameters in heifers that were administered short term PRID. KafKas Univ. Vet. Fak. Derg., 21(4): 569-573.

53. Aksu, E.H., Bozkurt, B. and Türk, G. (2010) Effect of Vitamin E on Reproductive Performance in Cows Synchronized with Different Synchronization Methods. Vol. 24. Conference: $7^{\text {th }}$ National Congress (with International Participation) on Animal Reproduction and Artificial Insemination. p71-76.

54. Kuru, M., Ögün, M., Oral, H., Kükürt, A., Makav, M. and Kulaksiz, R. (2016) The use of controlled internal drug release for synchronization augmented oxidative and nitrosative stress and leptin levels in Georgian goats. J. Cell.
Neurosci.Oxid. Stress, 8(1): 541-542.

55. Kuru, M., Ögün, M., Oral, H., Kükürt, A., Erkiliç, E.E. and Kulaksiz, R. (2016) Synchronization with Controlled Internal Drug Release CIDR on Exacerbate Oxidative and Nitrosative Stress and Leptin Levels in Abasian Goats. In: $12^{\text {th }}$ International Conference on Goats, International Goat Association, Antalya, Turkey. p191.

56. Gragasin, F.S., Xu, Y., Arenas, I.A., Kainth, N. and Davidge, S.T. (2003) Estrogen reduces angiotensin II-induced nitric oxide synthase and NAD (P) H oxidase expression in endothelial cells. Arterioscler. Thromb. Vasc. Biol., 23(1): 38-44.

$* * * * * * * *$ 